\title{
Van die teks van die Woord na die werklikheid
}

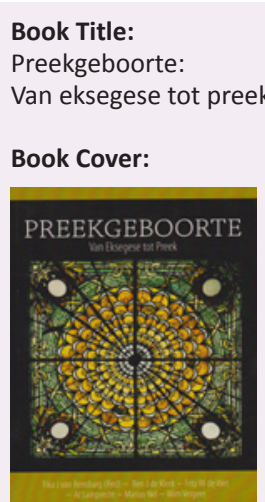

Authors:

F. Janse van Rensburg (red.)

B.J. de Klerk

F. de Wet

A. Lamprecht

M. Nel

W. Vergeer

ISBN:

Not available

\section{Publisher:}

Potchefstroomse Teologiese Publikasies, 2011, R92.00*

*Book price at time of review

Review Title:

Van die teks van die Woord

na die werklikheid

Reviewer:

C.J.H. (Cassie) Venter ${ }^{1}$

\section{Affiliation:}

${ }^{1}$ Department of Practical

Theology, North-West

University, Potchefstroom

Campus, South Africa

Email:

casmar@lantic.net

\section{Postal address:}

3 Agapanthus Street,

Welgedacht 7530

South Africa

How to cite this book review: Venter, C.J.H., 2012, 'Van die teks van die Woord na die werklikheid', In die Skriflig/In Luce Verbi 46(1), Art. \#656, 1 page. http//dx.doi.org/ 10.4102/ids.v46i1.656

(C) 2012. The Authors. Licensee: AOSIS OpenJournals. This work is licensed under the Creative Commons Attribution License.
Reeds in die voorwoord tot hierdie navorsing word gestel dat Preekgeboorte reeds in 1999 vir die eerste keer verskyn het (behartig deur twee outeurs, Van Rensburg en De Klerk), dat dit weer in 2005 in uitgebreide formaat verskyn het (vier outeurs), en dat die jongste uitgawe in 2011 behartig is deur agt outeurs.

Wie die inhoudsopgawes van die drie uitgawes nagaan en vergelyk, ervaar dat daar besliste groei en diepgang is, ook in die byvoeging van hoofstukke en outeurs.

Die oorkoepelende doel met die navorsing in Preekgeboorte is om elke bedienaar wat dié publikasie gebruik, uit watter kerklike tradisie ook al, toe te rus vir prediking met diepgang. As verskillende geboortefases van 'n preek word die volgende aangedui: die verkenningsfase van die perikoop en teks, die intensiewe fase, die formuleringsfase en die finale fase as geboorte van die preek. Wat besonder opvallend is, is dat 'n kardinale plek gegee word aan gebed om die inwerking van die Heilige Gees in die wetenskaplike werk deur al die fases van die preekgeboorte. Ware preekmaak is inderdaad wetenskaplike verkenningswerk, maar dan juis om die bedoeling van die Gees in 'n teks, perikoop of hoofstuk te begryp. Wie anders as die primêre Outeur weet immers die beste wat in 'n Bybelteks geskryf is? In die preekgeboorte is die bedienaar van die Woord die eerste een wat deur die Woord geraak (en verwond) word. Alleen só kan hy of sy die Woord aan mede-verwondes oordra. Deur eie verwonding in die omgang met die Woord ontspruit die verwondering oor die krag van die Heilige Gees in die proses van preekgeboorte.

Nadat die outeurs 'n aantal vertrekpunte oor die Bybel, die gesag van die Bybel en die voorwaardes vir die prediking vanuit die Bybelteks gebied het, word in diepte aandag gegee aan die verskillende fases van die geboorteproses van die preek. Op intensiewe wyse word beweeg van die fase van die bestudering van die grondteks in die die perikoop tot die konteks van die hoorder. Die formuleringsfase begin by die verrekening van die optrede van die prediker self as getuie in die preek proses.

Die finale proses van die 'geboorte' is die omvorming van die preek tot lewende verkondiging. Besinning oor die gebruik van visuele hulpmiddels in die oordragproses van die preek is insiggewend. Tog is dit duidelik dat hulpmiddels nie hoofsaak moet word in die oordra van die preekinhoud nie. Die hulpmiddel moet in laaste instansie nie belangriker word as die inhoud en verkondiging van die Woord self nie. Wat die hoorder moet bybly, is dit wat die Gees deur die verkondiging openbaar en nie die detail van byvoorbeeld ' $n$ PowerPoint-aanbieding nie!

'n Nuttige indeks van vaktaalterminologie en ook 'n bronnelys word aan die einde van die boek gegee.

Wat eerstens opval as na hierdie navorsing in sy geheel gekyk word, is die erns wat die outeurs maak met die werk van die Heilige Gees in die hele proses van tekskeuse tot oordrag van die preek. Hulle doen dit op 'n nederige wyse en in verwondering.

Tweedens is die deeglike aandag wat gewy word nie net aan die proses van eksegese nie, maar ook aan die proses van hermeneuse opvallend. In 'n preek ontmoet die teks uit die Woord en die teks uit die lewe (situasie) mekaar immers in 'n onderlinge wisselwerking.

Derdens word in hierdie werk besondere moeite gedoen met die ontvanger van die prediking deur byvoorbeeld aandag te wy aan die verskillende geloofstipes onder die hoorders, die tydsgees (postmodernisme), die verhouding tussen prediker en gemeente en oorredingstrategieë.

Hierdie boek word sterk aanbeveel vir die preektoerusting van voornemende en huidige predikante. Sou uit hierdie gegewens nie toerustingseminare gebore kon word vir voortgaande opleiding in preekgeboorte nie? Veral vir predikante en lidmate wat prediking op die hart dra. 